\title{
IAU President Walter Kamba (1990-1995): A Man of Conscience
}

\author{
Goolam Mohamedbhai
}

\section{First Encounter}

In June 1983, I participated, as representative of the University of Mauritius, in a training course on improving teaching and learning for academics from different African universities. It took place at the Roma campus of the National University of Lesotho. One afternoon, we were introduced to a distinguished guest speaker, Professor Walter Kamba, Vice-Chancellor of the University of Zimbabwe. He happened then to be visiting the university, and the organisers invited him to talk to us. Professor Kamba spoke, not about teaching and learning, but about the vital role African universities have to play in the continent's development, an issue that was highly topical at that time. His lengthy speech, delivered off-the-cuff, was remarkable and passionate. He was a formidable orator, and we were all enthralled. He left a lasting impression on me. Little did I know then that, seven years later, he would be the President of the International Association of Universities (IAU), and that I would follow in his footsteps some ten years after him.

\section{Early Years and Exile}

Walter Kamba was born in 1931 in the British colony of Southern Rhodesia. He went to study Law at the University of Cape Town in South Africa and then returned to Southern Rhodesia where he was one of the few black legal practitioners to the High Court. However, when a Universal Declaration of Independence was issued in 1965 in Southern Rhodesia, he fled the country with his family and went to the UK. He subsequently joined the Faculty of Law at the University of Dundee, Scotland, as

\footnotetext{
G. Mohamedbhai ( $\square)$

International Association of Universities, Paris, France

e-mail: g_t_mobhai@yahoo.co.uk 
Lecturer and spent over eleven years there as an academic, eventually even serving as Dean of Faculty. It was no doubt at the University of Dundee that he developed an appreciation of institutional autonomy and academic freedom in universities, values which guided him throughout the rest of his academic career. In 1982, in recognition of his outstanding contributions, the University of Dundee awarded him an honorary doctorate.

\section{Return to Zimbabwe}

Although he had a successful academic career at the University of Dundee, his heart was in Southern Rhodesia and, from the UK, he constantly followed the political developments there. Subsequently, he was closely involved as a legal adviser to the black nationalist movements in the preparations of his country's independence and even participated in the Lancaster House Conference in London, following which, in 1980, Southern Rhodesia became independent and was named Zimbabwe, and Robert Mugabe was elected its Prime Minister.

Walter Kamba then returned to Zimbabwe in 1980 and took up the position of Professor of Law at the re-named University of Zimbabwe, formerly University of Rhodesia. The following year, he was appointed Vice-Chancellor of the university, the first black academic to take up such a position at that institution.

\section{Vice-Chancellor}

By all accounts, the first five years of Walter Kamba's tenure as Vice-Chancellor were successful. He managed to significantly expand the university, both in terms of increasing student enrollment, especially black Zimbabweans, and the range of courses offered, and bring about positive transformation. He was fair and consultative, and his leadership was appreciated by staff, students and also the government. He realised that the success of a developmental university in the context of a nascent, independent African country needed understanding and close communication between university and government. In a paper he wrote in 1985 for the National University of Lesotho, he expounded his views on the need for compromise between university and government with regard to institutional autonomy and academic freedom (Kamba 1985). Here are some excerpts:

"The development of the university is dependent on the support of those who work in it and on the availability of resources from the government. If the university accepts that university autonomy and academic freedom can only be perceived in the socio-economic context in which it operates, and that it depends on the goodwill of the nation and the sense of responsibility of the academic staff; if the government accepts that the university needs a certain amount of autonomy to carry out its mission effectively and efficiently, then there need not be a conflict between national 
aspirations and academic integrity. Any unbridled provincialism on the part of the university is as threatening to public and national interest, as is the desire of the state to police the university for the sake of control itself. Put differently, some state control is inescapable just as some substantial degree of institutional autonomy is indispensable. This is a balance which needs to be worked at, all the time. The task is to develop consultative relationships that bring the legitimate concerns of the university and the legitimate concerns of government into shared perspectives." These words of wisdom and guidance are remarkable and relevant to public universities in Africa even today. However, by his reference to 'unbridled provincialism on the part of the university', and the 'desire of the state to police the university', one can sense his uneasiness and his intuition that a storm was gathering on his campus.

\section{University Autonomy Threatened}

Indeed, soon after, the situation at the University of Zimbabwe started to deteriorate, to a large extent resulting from the ethnic strife, economic decline, dividing politics and corruption in the country. Walter Kamba himself openly acknowledged in a speech that there had been serious problems during the last few years of his tenure. In 1988, the students of the University of Zimbabwe decided to hold a demonstration on campus to protest against an alleged corruption scandal involving government officials (Magasia 2015). The government sent in anti-riot police to the campus to block that demonstration. A year later, in 1989, the students planned to hold a public seminar to commemorate the events of 1988. The government issued a ban on the seminar and sent in the police to the campus, which led to the arrest of some student leaders and even those who openly supported the students. The students retaliated and decided to boycott lectures, and this eventually resulted in the closure of the university.

The worst was to come in the following year. In order to have greater control over the university, in 1990 the government legislated to amend the 1982 University of Zimbabwe Act. The main amendments aimed at authorising the President, instead of the University Council, to appoint the Vice-Chancellor; at significantly increasing the number of government-appointed members on the University Council; and at assigning powers to the Vice-Chancellor to expel or suspend students, dissolve or suspend the Students' Union and prohibit or suspend any of the Union's activities. Both students and academics, including Walter Kamba, vehemently protested against the amendments which were clearly meant to undermine the University's autonomy, but their voices went unheeded.

It was in that same year that Walter Kamba was elected President of IAU for the period 1990-1995. He was the first President from an African country since the creation of the association in 1950 . 


\section{Graduation Ceremony Speech}

Walter Kamba now faced a dilemma. He was President of IAU, an international organisation that had a strong commitment to university autonomy and academic freedom, in which he staunchly believed, and yet, the university he headed was taking steps to flout the very same principles. As a lawyer, he knew that he would, sooner or later, be forced to implement the amended legislation of his university. He must have realised that he had no option but to leave.

At the 1991 Graduation Ceremony of the University, in the presence of President Robert Mugabe, the University's Chancellor, Walter Kamba made the following audacious remarks in his welcome address and announced his departure (NORRAG 1991).

"Your Excellency and Chancellor, there are too many fingers in the affairs of the University - non-professional fingers with a wide range of agenda. I accept that we live in times in which the only constant variable is change. But for me, professionalism is at the heart of academia. I was appointed purely and entirely for my professionalism. I am a professional at heart, I am a professional by experience, dedication and commitment. I have never and will never play games... In September this year, I will be submitting my notice of retirement as Vice-Chancellor of the University of Zimbabwe."

Kamba's message to President Mugabe was clear: he was not prepared to accept political interference which would undermine the University's autonomy. Earlier in the same speech, he also hinted at the threat to academic freedom on campus:

"I am convinced that intellectual enquiry and excellence will flourish in an environment that encourages dialogue, tolerance and humility. Fear to criticise is not only inimical to free scientific inquiry but also to creativity. For this reason, it is the obligation of the University to restore faith in rational and informed disputation."

There had been reports that there were political spies lurking on campus and present even during lectures, and they would report to authorities what was being discussed, by whom and what events were being planned. Staff and students were, therefore, afraid to openly discuss issues on campus. No doubt this was the reason why Walter Kamba made reference to 'fear to criticise' in his speech.

One could argue that Walter Kamba should have stayed on and, using his influence in Zimbabwe and elsewhere, especially as he then held the distinguished position of IAU President, try to improve the University's situation. But Kamba must have known that his efforts would be futile. He was undoubtedly aware that Mugabe had become very powerful in Zimbabwe and was utilising his notorious infantry "5th Brigade" to crush any insurgency. As a man of conscience, he could not continue.

At the end of his Graduation Ceremony speech, he made the following iconic statement:

"Whatever I do, my conscience is my master. When my epitaph comes to be written, I will be satisfied if the inscription reads: Here lies a man whose master was his own conscience." 


\section{University of Zimbabwe Post-Kamba}

During most of the 1990s following Walter Kamba's departure, student protests increased at the University of Zimbabwe, resulting in student arrests, campus closures and mass expulsions. The situation became worse after 2000 with the approach of presidential elections in 2002. Perhaps the most extreme example of loss of institutional autonomy at the University of Zimbabwe was the award in 2014 of a doctorate degree in sociology to Grace Mugabe, the President's wife, only two months after she had registered on the programme. Other senior members of Robert Mugabe's regime were also believed to have been awarded doctorate degrees without the submission of any dissertation. This became the rallying cause of campus protests in 2017 when the students refused to sit for their examinations until Grace Mugabe's Ph.D. had been revoked, and Robert Mugabe had resigned as President.

The protests had, for once, a direct impact and soon led to the resignation of Mugabe in November 2017. The students of the University of Zimbabwe have been hailed as being the ones who finally succeeded in pushing Mugabe to resign, thus ending his reign of 37 years. He died two years later at the age of 95 .

\section{Later Years}

After leaving the University of Zimbabwe, Walter Kamba moved to the University of Namibia where he set up the Faculty of Law and was Professor of Human Rights and the founding Dean of the Faculty. But he continued to be of service to his country and the University of Zimbabwe, and he was assigned several important assignments. For example, in 1999 he was appointed Vice-Chairman of the Constitutional Commission, set up with Mugabe's agreement, to advise on a process for Mugabe's retirement; the Commission's proposals, however, were never implemented. And until his death, he was the Herbert Chitepo UNESCO Professor of Human Rights, Democracy, Peace and Governance at the University of Zimbabwe.

Professor Walter Kamba passed away in 2007 at the age of 75 after a long illness. At that time, I was President of IAU, having been elected in 2004, and I became the second IAU President from a university in Africa.

\section{IAU and Academic Freedom/ University Autonomy}

Academic freedom and university autonomy, values that were so dear to Walter Kamba, are principles on which the IAU was founded in 1950. In 1998, on the occasion of the UNESCO World Conference on Higher Education, the IAU published a comprehensive Policy Statement on 'Academic Freedom, University Autonomy and Social Responsibility'. 
Twenty years later, these values remain pertinent to the IAU. In the 'In Focus' section of the January 2018 issue of its magazine 'IAU Horizons', the IAU published the views of seventeen international authors covering higher education systems in countries from almost all regions of the world on whether academic freedom and university autonomy were under threat. Their reflections appear to indicate that while the understanding and prevalence of academic freedom and university autonomy vary from region to region, generally, these principles are currently under threat in most countries.

\section{University Autonomy in Africa}

With regard to Africa, there has hardly been any improvement in university autonomy. In many African countries, the executive head of the public university is still directly appointed by the government; there is heavy representation of government on the university's governing Council, and the responsible minister can give directives to the Council which the latter has to implement. Also, many African universities are experiencing political infiltration of their students' union. One can hardly expect university autonomy to thrive in such conditions.

This situation is, no doubt, a consequence of the state of democracy in Africa. According to the 2019 democratic index of the Economist Intelligence Unit, $50 \%$ of African countries have an authoritarian regime and, generally, democracy has been declining on the African continent.

African universities have a role to play in promoting democracy in Africa and in helping to achieve university autonomy. However, for this to happen, both the countries and the universities need to have committed and honest leaders who have a conscience, men and women of the mettle of Walter Kamba.

\section{References}

Kamba, W. (1985). The Response of Institutions of Higher Learning to Africa's Rapidly Deteriorating Social and Economic Conditions. ISAS Occasional Paper No. 2, Institute of Southern African Studies, National University of Lesotho. Retrieved from: https://core.ac.uk/download/ pdf/29136835.pdf (17.03.2020).

Magasia, A. T. (2015). How Mugabe strangled the students' movement in Zimbabwe (Part 2). Retrieved from: https://nehandaradio.com/2015/10/28/how-mugabe-strangled-the-studentsmovement-in-zimbabwe-part-2/ (17.03.2020)

NORRAG News. (1991). Excerpts from the Address of Welcome, Graduation Day, University of Zimbabwe. 1 July 1991 by Walter Kamba, Vice-Chancellor. Retrieved from: www.norrag.org/ fileadmin/Full\%20Versions/NN11.pdf (17.03.2020) 
Goolam Mohamedbhai is former secretary-general of the Association of African Universities, the former president of the International Association of Universities, the former vice-chancellor of the University of Mauritius and a former member and vice-chair of the governing council of the United Nations University. He is currently a member of the Board of the University World News (Africa). His main interest is African higher education about which he has written and spoken widely.

Open Access This chapter is licensed under the terms of the Creative Commons Attribution 4.0 International License (http://creativecommons.org/licenses/by/4.0/), which permits use, sharing, adaptation, distribution and reproduction in any medium or format, as long as you give appropriate credit to the original author(s) and the source, provide a link to the Creative Commons license and indicate if changes were made.

The images or other third party material in this chapter are included in the chapter's Creative Commons license, unless indicated otherwise in a credit line to the material. If material is not included in the chapter's Creative Commons license and your intended use is not permitted by statutory regulation or exceeds the permitted use, you will need to obtain permission directly from the copyright holder. 